\title{
A Comparative Study on the Strategies Adopted by the United Kingdom, India, China, Italy, and Saudi Arabia to Contain the Spread of the COVID-19 Pandemic
}

This article was published in the following Dove Press journal:

Journal of Healthcare Leadership

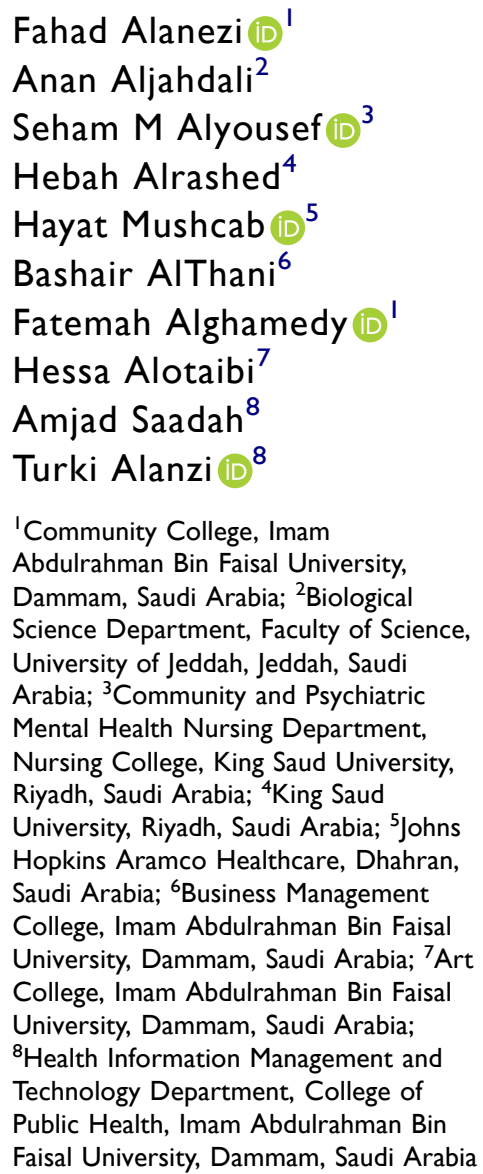

Correspondence: Turki Alanzi Health Information Management and Technology Department, College of Public Health, Imam Abdulrahman Bin Faisal University, King Faisal Road, Dammam 3|44I, Saudi Arabia

$\mathrm{Tel} / \mathrm{Fax}+966$ I3333I2II

Email talanzi@iau.edu.sa
Purpose: The objective of this study was to compare the strategies adopted by the United Kingdom, Italy, China, India, and Saudi Arabia to contain the spread of the COVID-19 pandemic. Materials and Methods: A review of the literature was carried out to collect data on the strategies used by China, Italy, India, the United Kingdom, and Saudi Arabia to contain the spread of the COVID-19 virus. The global analysis of 65 published literature references allowed observing the effectiveness and efficiency of the strategies used by these countries to control the spread of the COVID-19 virus.

Results: Both mitigation and suppression strategies were adopted by the United Kingdom, India, Italy, China, and Saudi Arabia to control the spread of the COVID-19 pandemic. It was observed that China has achieved a greater success in flattening the curve compared to the other countries. In China, few new daily cases have occurred since March, and it has been the only country that has managed to keep the COVID-19 pandemic under control. On the other hand, reductions in the number of daily cases (since May 2020) were detected in the United Kingdom, Italy, and Saudi Arabia (since July 2020). Also, during the last 3 months (June, July and August) India has shown the highest growth in the total number of confirmed cases and in the number of new daily cases, compared to the mentioned countries.

Conclusion: The review of the strategies adopted by China, India, the United Kingdom, Italy and Saudi Arabia to combat the COVID-19 pandemic can guide countries in the design and development of mitigation and suppression approaches to control the spread of the COVID-19 virus. Containment strategies such as lockdowns cannot continue in the long term. Therefore, countries must adopt mitigation and prevention strategies to protect people from infection and learn to live with the virus.

Keywords: COVID-19 outbreak, mitigation and suppression strategies, lockdown strategy, novel coronavirus, pandemic

\section{Introduction}

The ongoing COVID-19 pandemic has severely impacted people, businesses, institutions, and governments across the globe. This pandemic is caused by a novel virus belonging to the family of coronaviruses, which is usually referred to as Severe Acute Respiratory Syndrome Coronavirus 2 (SARS-CoV2). ${ }^{1}$ It was first observed in December 2019 in Wuhan, China, and rapidly the virus spread across various countries. $^{2}$ 
This ongoing pandemic results in an increasing number of deaths and affects people with the compromised immune system. On September 1, 2020, there were across the globe 29,060,747 of confirmed cases and 913,892 deaths. ${ }^{3}$ The USA is leading with 5,936,572 of confirmed cases and 182,162 deaths, followed by Brazil $(3,862,311$ confirmed cases and 120,888 deaths), Russia (1,000,048 confirmed cases and 17,299 deaths), and the United Kingdom (335,872 confirmed cases and 41,501 deaths). ${ }^{3}$

Initial symptoms of COVID-19 may include fever, cough, shortness of breath; however, new symptoms such as loss of smell and taste, fatigue, blood clots, and complications related to Acute Respiratory Distress Syndrome (ARDS) have been identified as the disease progressed., ${ }^{2,4-6}$ The virus usually spreads through the droplets produced by coughing, sneezing, or talking. ${ }^{6,7}$ These droplets can fall on various surfaces that can become contaminated with the virus, and people can be infected by touching the surfaces or by coming into close contact with infected persons. ${ }^{7-9}$ Infectivity rate is used to identify the reproduction number (R0) of COVID-19, which varies between 1.5 and 3 indicating that each COVID-19 patient can infect on an average of up to three other people. ${ }^{10}$

Accordingly, mitigation and suppression strategies have being formulated to reduce R0 to less than one, in order to control the pandemic. ${ }^{10,11}$ Mitigation approaches such as social distancing, quarantine, isolation, and other measures focus on slowing the spread of the pandemic, but without interrupting transmission entirely to ensure that healthcare services are provided for those who are at a high risk of developing the infection. ${ }^{10}$ Suppression strategies are concentrated on reversing the spread of the pandemic by reducing the infection rate by implementing Non-Pharmaceutical Interventions (NPI) such as strict lockdowns, social distancing, closing of schools, community places, businesses, and other interventions; these measures can be maintained for 18 months or until vaccines are developed. ${ }^{11}$ Mitigation strategies may not be effective in reducing $\mathrm{R} 0$ to less than one, compared to suppression strategies. This has been observed in countries such as Singapore, China, and Taiwan which have managed to keep COVID-19 cases low due to the strict implementation of suppression strategies. Their previous experience in relation to SARS-COV1 helped them to implement strict travel restrictions, rapid screening and contact tracing. ${ }^{12}$ In addition, the $\mathrm{R} 0$ has varied between the different regions, which have become one of the main challenges for the development of containment strategies by governments. ${ }^{13}$ It was also revealed that there could be asymptomatic cases, which cannot be detected, but can be a major carrier of the virus and a source of transmission. ${ }^{14}$ The large differences in the number of cases and the number of deaths, the risk of transmission, and challenges such as asymptomatic carriers are some important aspects to consider when developing containment strategies.

Different countries have adopted various strategies such as social distancing, quarantine, isolation, lockdowns, curfews, travel restrictions, schools/colleges closing, and so forth, to contain the spread of the COVID-19 virus and have produced variable results. ${ }^{15}$ Focusing on these aspects, the objective of this study was to compare the strategies adopted by the United Kingdom, Italy, China, India, and Saudi Arabia to contain the spread of the COVID-19 pandemic. This comparative analysis can be useful to observe the effectiveness and efficiency of the strategies used by these countries and can help to decide the future course of action to control the spread of the COVID-19 virus in other regions of the world.

\section{United Kingdom}

The United Kingdom (UK) is one of the most affected countries by the COVID-19 pandemic. In this country, 335,877 cases and 41,501 deaths have been confirmed from January 31, 2020 to September 1, 2020. ${ }^{16}$

Initially, the UK implemented a strategy focused on building people's immunity letting the virus to spread to about half of the population. ${ }^{17}$ However, as the number of positive cases increased, the government changed its strategy of mitigation to a suppression approach (lockdown). ${ }^{17}$

The lockdown suppression strategy was started on March 24, 2020, and all businesses, educational institutions, except healthcare and essential goods supplies, were closed. ${ }^{17}$

The government has eased the lockdown restrictions since June 1, 2020, though the risk of COVID-19 transmission is observed to be high. ${ }^{18}$ In addition, more emphasis has been placed on testing, tracking, prevention, and use of contact-tracing technologies. ${ }^{18,19}$

\section{India}

India has recorded 3,691,166 confirmed COVID-19 cases with 65,288 deaths between January 30, 2020, and September $1,2020 .^{20}$ The country implemented a nationwide lockdown on March 22, 2020, and adopted various 
suppression and mitigation strategies through five phased lockdowns since March 22, 2020. ${ }^{21,22}$

High population density, with large population groups below the poverty datum line, lack of medical equipment such as testing kits and other medical supplies are some of the main challenges identified to contain the spread of COVID-19 in this country. However, the country had done well in the first three phases of the lockdown from March 22 to May $17 .^{22,23}$ The country's testing strategy focused on risk and priority, where people with COVID-19 symptoms and a recent history of international travel were identified for testing, rather than adopting a mass testing strategy which can be a complex task given the population and the availability of resources. ${ }^{21,22,24}$ The strategy has worked well, and many positive cases were identified. In addition, India saw the herd immunity strategy as an approach to contain the virus, by launching campaigns for healthy foods, mandatory medicines such as arsenic albumin and hydroxychloroquine. ${ }^{25}$ Recovery rate is found to be increased (48\%) with a reduction of the fatality rate $(3.15 \%)$ as of May $18,2020 .^{26}$

Focusing on the technology front, the country has launched the mobile contact-tracing application called "Arogya Setu", which was found to be very useful in identifying the contaminated zones that were under strict lockdown due to the high number of recorded COVID-19 cases. It was downloaded and subscribed by more than 100 million users within 40 days of its launch, and 3000 hotspots in 3-17 days ahead of time were installed. ${ }^{27,28}$

The country has adopted various flexible strategies according to the situation analysis. One of the effective strategies included the cluster containment strategy, where cases were detected early in high-risk zones, and the areas were marked as containment zones; in these areas, complete lockdowns were implemented. ${ }^{29,30}$ Before closing the lockdown on June 1, 2020, different zones related to COVID-19 contamination were marked in four categories (containment, red, orange, and green zones) depending on the risk of contamination: green areas correspond to zones where there are no positive cases of COVID-19; orange areas are those where there have been a limited number of cases in the past, and there have not been a recent increase in positive cases; and, red zones, also called contaminated zones, are completely blocked due to the large number of COVID-19 cases. According to the rules, depending on the mentioned categories, the lockdown has been eased in different areas, while the complete lockdown has continued in containment and red zones. ${ }^{31}$
With the strict implementation of lockdown in containment areas, the country has eased most of the restrictions, facilitating the operations of all entities and the society.

\section{China}

China has confirmed 90,402 cases of COVID-19 with 4730 deaths between January 11, 2020, and September 1, $2020 .^{32}$ On 23 January 2020, the central government of China imposed a lockdown in Wuhan and other cities in Hubei in an effort to quarantine the center of the 2019 coronavirus (COVID-19) outbreak. ${ }^{33}$

Since then, China, being the epicenter of the COVID19 outbreak has adopted various strategies to contain the spread of the virus. The strategies have been designed and adopted rapidly, and effective planning and implantation of health intervention strategies have been highly successful in containing the COVID-19 virus. ${ }^{33-35}$ Public health interventions such as early case detection, contact tracing, population behavioral change, and the creation of essential resources such as hospitals and the use of existing primary care centers specifically for the treatment of COVID-19 have contributed to contain the epidemic effectively. ${ }^{34}$ In addition, China has used advanced technologies such as Artificial Intelligence (AI) and Machine Learning (ML) to develop applications, which can be used for contact tracing, medical diagnosis, and other COVID-19 operations. Drones were used for tracking, contact tracing, and also for services delivery in China, ensuring that people stay at home and their needs were met. ${ }^{36}$ Similarly, robots were used in various services including hospitals, restaurants, and other areas, limiting human interactions during the epidemic. $^{37}$ Rapid innovations in biotechnology were made, including the development of a new food line with ingredients that boost the immune system. ${ }^{38}$ Also, hi-tech face masks, free online clinics, and use of AI and ML techniques to diagnose COVID-19 (just by looking at CT scans) were developed. ${ }^{39}$ The implantation of virtual classrooms, remote working, unmanned automated retail stores were other approaches implemented during COVID-19 outbreak to reduce contamination. ${ }^{39}$ On April 8, after 76 days, China lifted the lockdown in Wuhan and reopened companies and universities in a progressive and careful manner.

\section{Italy}

Italy has recorded 269,214 confirmed COVID-19 cases with 35,483 deaths from 30 January 30, 2020 to September $1,2020 .^{40}$ Italy was the most affected country 
besides China, in the initial days of the pandemic, before it spread across Europe, and the USA. The first case in Italy was reported on February 21, prompting a national lockdown on March 11, as the epidemic had rapidly spread throughout Italy. ${ }^{41}$ The causes of the rapid spread and a large number of deaths in Italy were attributed to free mobility, socializing behaviors, and a large number of aging people. ${ }^{42}$

Although Italy has an effective and efficient healthcare system, the rapid increase in the number of COVID-19 patients has put the system under stress, and on the brink of collapse. ${ }^{15}$ However, the quick actions taken by the government in the implementation of containment and lockdown strategies, and the emergency responses of the healthcare system have helped to manage the pandemic. ${ }^{41}$ Its strategy focused on containing the infected zones through lockdown, rapid tests, and ensuring availability of healthcare services for the infected persons. ${ }^{43}$ ICUs of several hospitals were vacated, regular hospitalized patients were transferred to non-containment zones for the availability of beds in the infected zones, and rapid changes in the delivery of care according to the increase of patients were implemented in the country. ${ }^{41-44}$ The country started easing the lockdown restrictions since May 4, $2020 .^{44}$

\section{Saudi Arabia}

Saudi Arabia has registered 315,772 confirmed COVID-19 cases with 3897 deaths between March 2, 2020, and September 1, 2020. ${ }^{45}$

It is pertinent to comment that Saudi Arabia has unique demographic characteristics, compared to the other countries considered in this study, that may contribute to the spread of the COVID-19 virus. In particular, more than $80 \%$ of its population lives in urban areas, with frequent family gatherings that present a high risk of contamination. $^{46,47}$

The country's initial approach to contain the spread of the COVID-19 pandemic was focused on mitigation strategies, which led to the strict implementation of social distancing. In addition, previous experience in dealing with similar outbreaks, including Middle East Respiratory Syndrome (MERS), SARS, and Ebola has helped the country to take precautions and develop containment interventions. ${ }^{48}$ However, as the number of infections continued to increase, strict containment measures were taken since the last week of February, such as the closure of Mecca and Madinah cities, closure of cultural events, and mass gatherings. ${ }^{49}$ The following containment strategies were slowly implemented throughout February and March: Umrah suspension (27/02/ $2020)$; cancelation and restriction of sporting events $(07 / 03 /$ 2020); closure of educational institutions (09/03/2020); suspension of sport competitions and banning of social events (14/03/2020); closure of shopping malls, restaurants, coffee shops, public parks (15/03/2020); suspension of daily and Friday prayer in mosques (17/03/2020); suspension of public transport, flights, trains, buses and taxis (18/03/2020); partial curfew (23/03/2020). ${ }^{49}$ Mass gatherings during Ramadan period in Mecca that could have increased the spread of infection were suspended. Therefore, the closure of holy shrines was one of the bold decisions taken by the government, which was fundamental for the mitigation of the pandemic. $^{50}$ With the experience gained in controlling MERS, the country's initial strategy focused on mitigation. ${ }^{51}$ However, the country slowly moved towards suppression strategies by implementing curfews and lockdowns through April-May. ${ }^{49-51}$ Although the country began to ease the lockdown restrictions since the end of May, the curfew continued until June 21, 2020. ${ }^{52-54}$

Additionally, Saudi Arabia's recent investments in the technology sector have been shown to have paid off with the use of technology interventions to combat COVID-19. Various services were provided to the public through mobile applications (for example, MAWID application for booking appointments), and drone technology was used for contact tracing and surveillance. ${ }^{55}$ Thus, Saudi Arabia's containment strategy focuses on both mitigation and suppression approaches alongside technology interventions to prevent the spread of the virus.

\section{Materials and Methods}

In this study, a review of the literature was carried out to collect and analyze data on the strategies used by China, Italy, India, the United Kingdom, and Saudi Arabia to contain the spread of the COVID-19 virus.

A total of 65 published literature references were analyzed to respond to the research question of this study. In particular, data provided by the World Health Organization (WHO) made it possible to make a comparison of the evolution of the pandemic from January 2020 to September 2020. This information on the confirmed cases of COVID-19 in the aforementioned countries appears in the following WHO references: United Kingdom, ${ }^{14}$ India, ${ }^{20}$ China, ${ }^{32}$ Italy ${ }^{40}$ and Saudi Arabia. ${ }^{45}$ The global analysis of the information provided in the literature allowed observing the effectiveness 
and efficiency of the strategies used by these countries to control the spread of the COVID-19 virus.

\section{Results}

The information on the total number of confirmed COVID-19 cases and the number of daily cases of COVID-19 in the United Kingdom in the period January 2020-September 2020 is shown in Figure 1A and B, respectively. Likewise, similar information for India is displayed in Figure 2A and B. Analogous data for China is depicted in Figure $3 \mathrm{~A}$ and B. Figure $4 \mathrm{~A}$ and $\mathrm{B}$ present the statistics for Italy, and Figure $5 \mathrm{~A}$ and $\mathrm{B}$ describe the data for Saudi Arabia.
On the other hand, a comparison of the total of confirmed COVID-19 cases in the United Kingdom, India, China, Italy, and Saudi Arabia in the period January 2020-September 2020 is described in Figure 6A. Alike, Figure 6B compares the daily cases of COVID-19 in the aforementioned countries.

Finally, Table 1 summarizes and compares the mitigation and suppression strategies implemented in each of the countries investigated in this study.

\section{Discussion}

The results of this research revealed that China, India, the United Kingdom, Italy, and Saudi Arabia have adopted
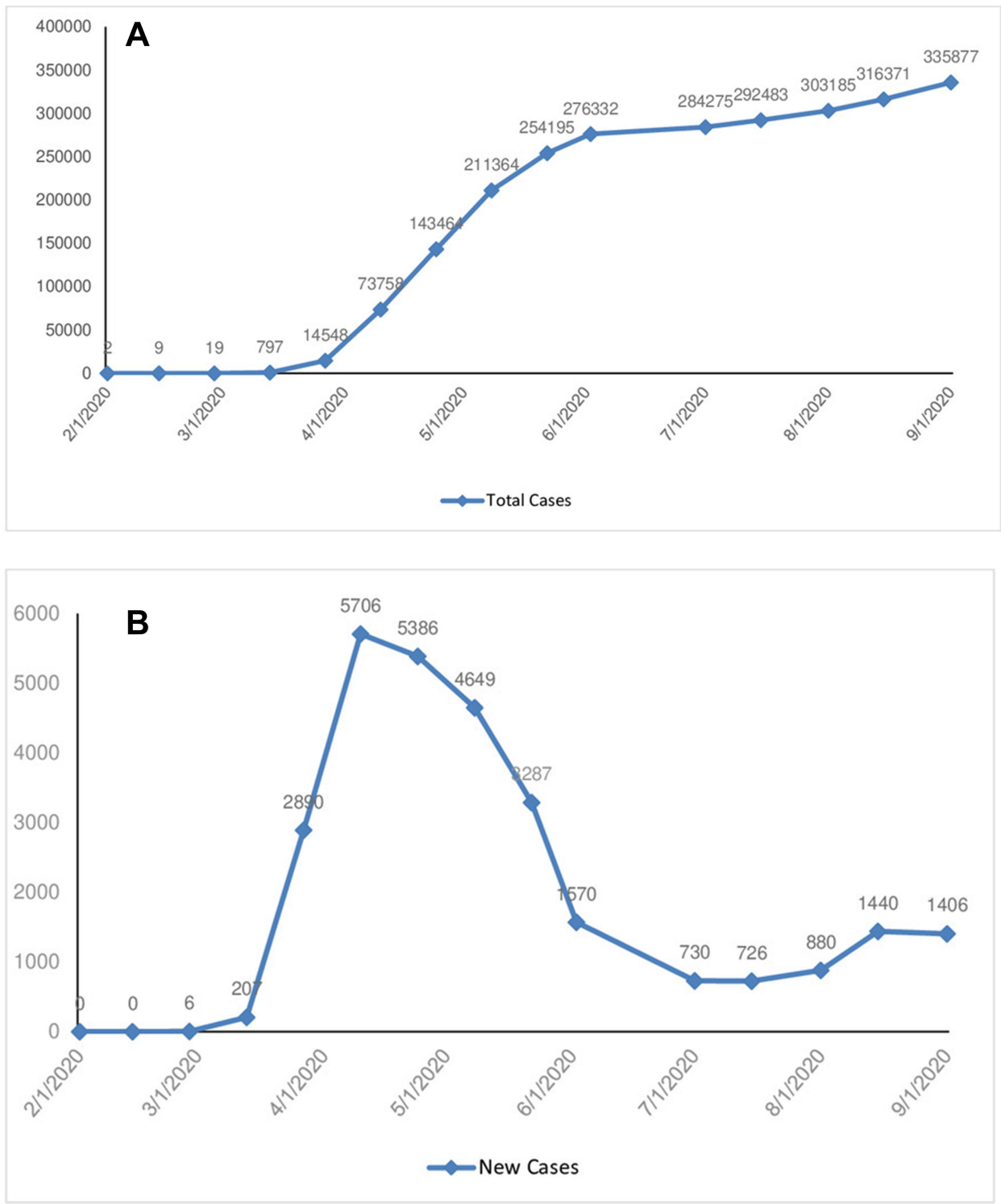

Figure I (A) Total COVID-19 cases in the United Kingdom. (B) Daily new cases of COVID-19 in the United Kingdom. 

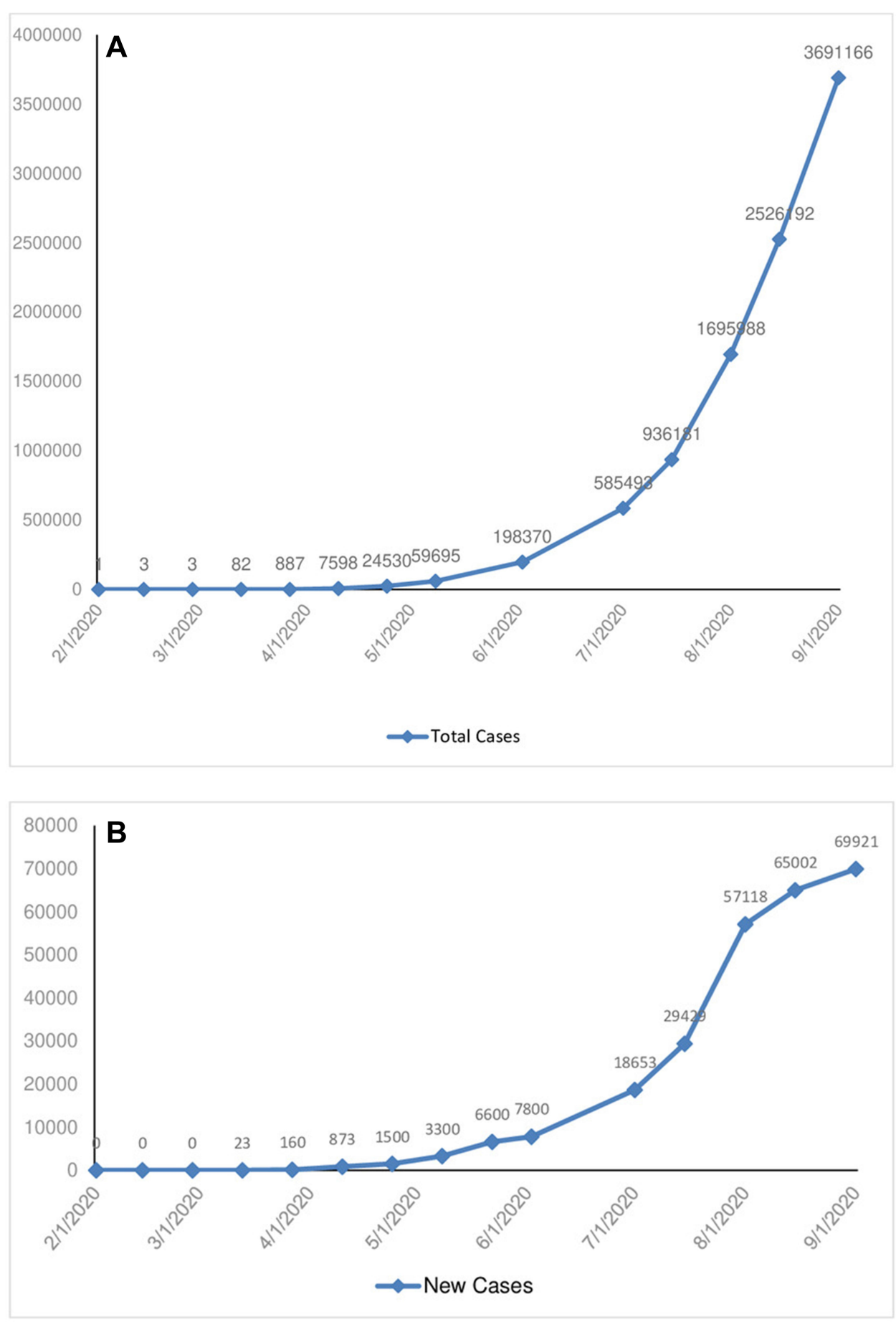

Figure 2 (A) Daily new cases of COVID-19 in India. (B) Daily new cases of COVID-19 in India.

different strategies to contain the spread of the COVID-19 pandemic. These strategies are shown in Table 1. Most of the strategies are based on the WHO guidelines that have clearly established the following approaches to respond to the COVID-19 pandemic: 1) conduct intensive testing; 2) trace contacts; 3) quarantine; and 4) keep social distancing. ${ }^{56}$ Although all countries have adopted these strategies (Table 1), they vary in the application of the mitigation and suppression approaches.

Regarding the United Kingdom, this country initially adopted a strategy that focused on building herd immunity and allowing the virus to spread to about $60 \%$ of the population. ${ }^{57,58}$ As there is no evidence on the development of herd immunity or suppression measures practices, 


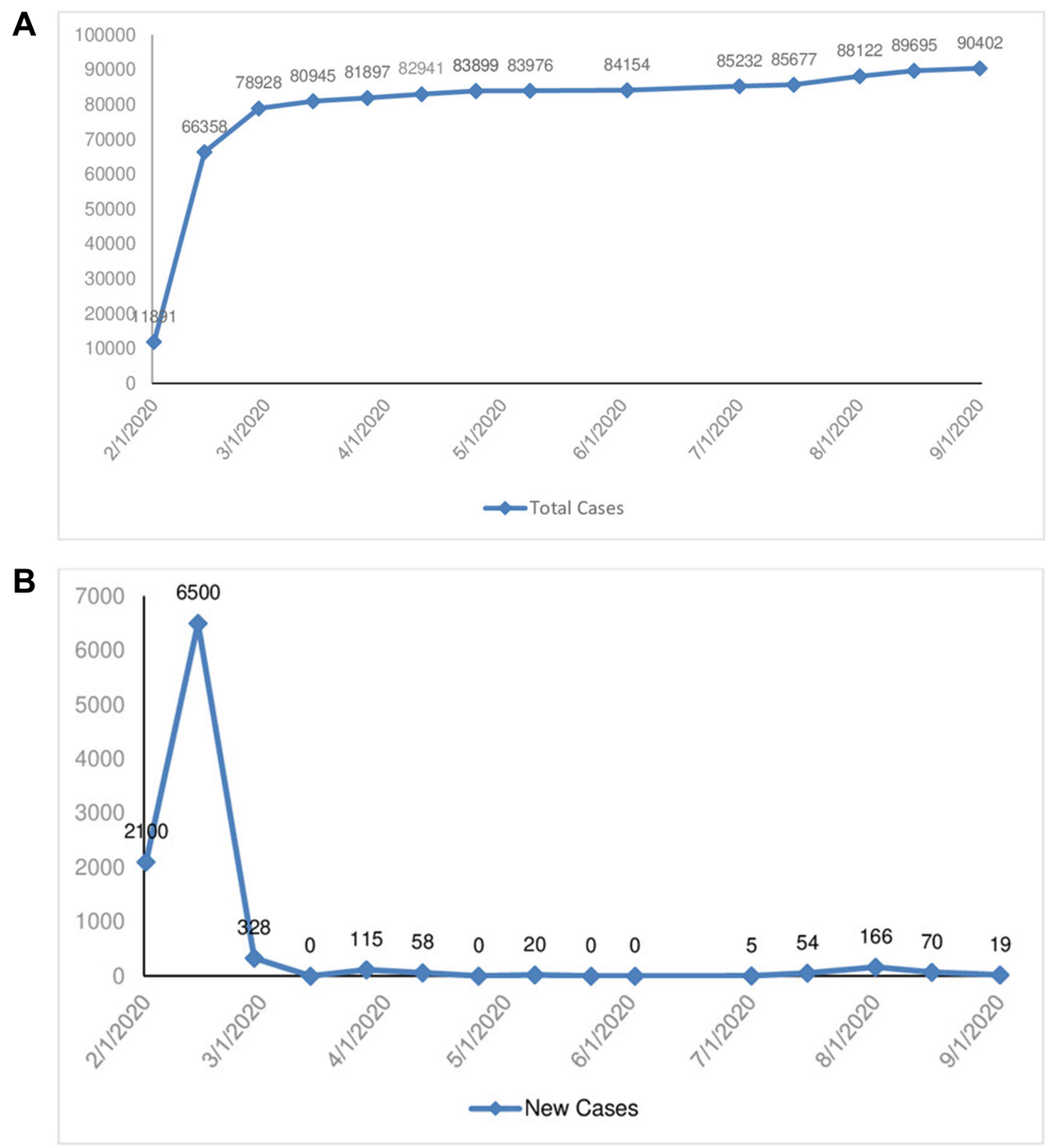

Figure 3 (A) Total COVID-19 cases in China. (B) Daily new cases of COVID-19 in China.

the UK should not have put the population at risk by implementing a herd immunity approach. However, the country changed its strategy of mitigation to a suppression approach (lockdown), as the number of positive cases increased. ${ }^{23}$ As shown in Figure 1A, despite the lockdown, the total number of confirmed COVID-19 cases in the UK has increased rapidly, revealing that the strategy could have been inadequately applied or lately implemented. ${ }^{23}$ Comparing the number of new daily cases (Figure 1B), there was a steady decrease since the second week of April, after implementing the lockdown, which can be attributed to the application of this strategy. ${ }^{23}$ However, it remains a major concern as there is a steady increase in the number of cases. Furthermore, public confidence in the government regarding the COVID-19 pandemic has fallen sharply, and many violations of the lockdown have been observed in recent days. ${ }^{59}$

India has focused on the suppression strategy, implementing a strict lockdown since March 22, 2020. Figure 2A and B suggest that regardless of the lockdown, the total confirmed COVID-19 cases in India have increased rapidly since the lockdown was implemented, revealing that the strategy may have been ineffective or poorly applied, or lately implemented. ${ }^{60}$ Furthermore, Figure 2B shows a surge in the number of new daily cases. This can be attributed to the appearance of new cases in major densely populated cities such as Mumbai, Delhi, Chennai, and other places where $40 \%$ to $50 \%$ of total confirmed cases have been found. ${ }^{60}$

In relation to China, this country adopted a containment and suppression strategy strictly applying the WHO 

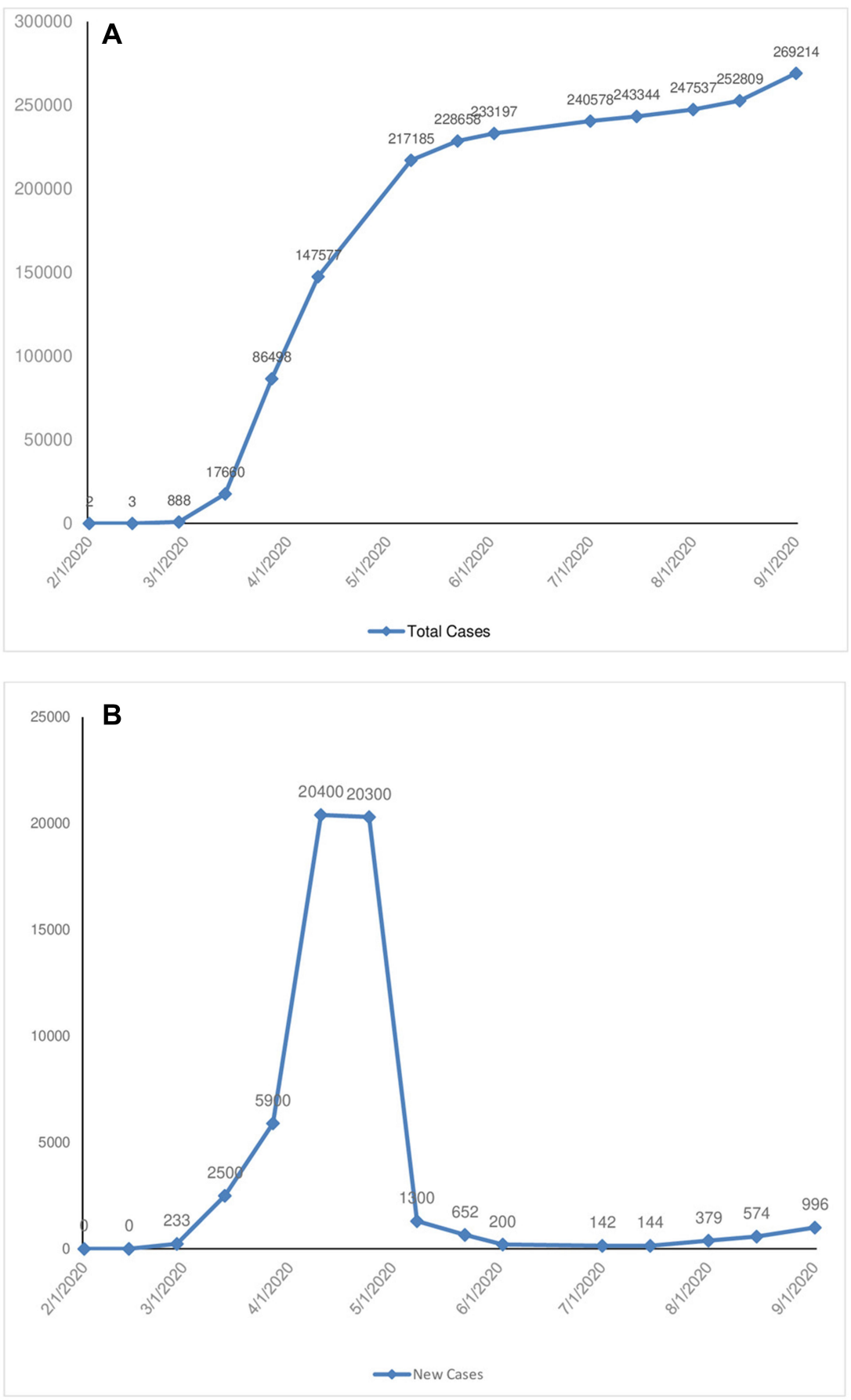

Figure 4 (A) Total COVID-19 cases in Italy. (B) Daily new cases of COVID-19 in Italy.

recommendations for extensive testing. Mobile test centers were established in the country and the response time for tests was reduced from 4 days to 4 hours. ${ }^{61}$ Family groups were identified and quarantined. In addition, various technological interventions such as mobile applications and drones were implemented to track and trace the movement of people in quarantine, trace contacts, and monitor the outbreak. $^{62}$ Countries such as South Korea, Japan,
Singapore, and Taiwan have adopted a similar strategy with minor changes. ${ }^{61,62}$ As shown in Figure $3 \mathrm{~A}$, the total number of confirmed COVID-19 cases experienced a rapid increase in the months of February and March, but the curve tended to flatten during April-May with an increase of 2000-3000 of confirmed cases. As a consequence, China has managed to flatten its curve (Figure $3 \mathrm{~A}$ ), with very few new daily cases of COVID-19 (Figure 3B) during the past 

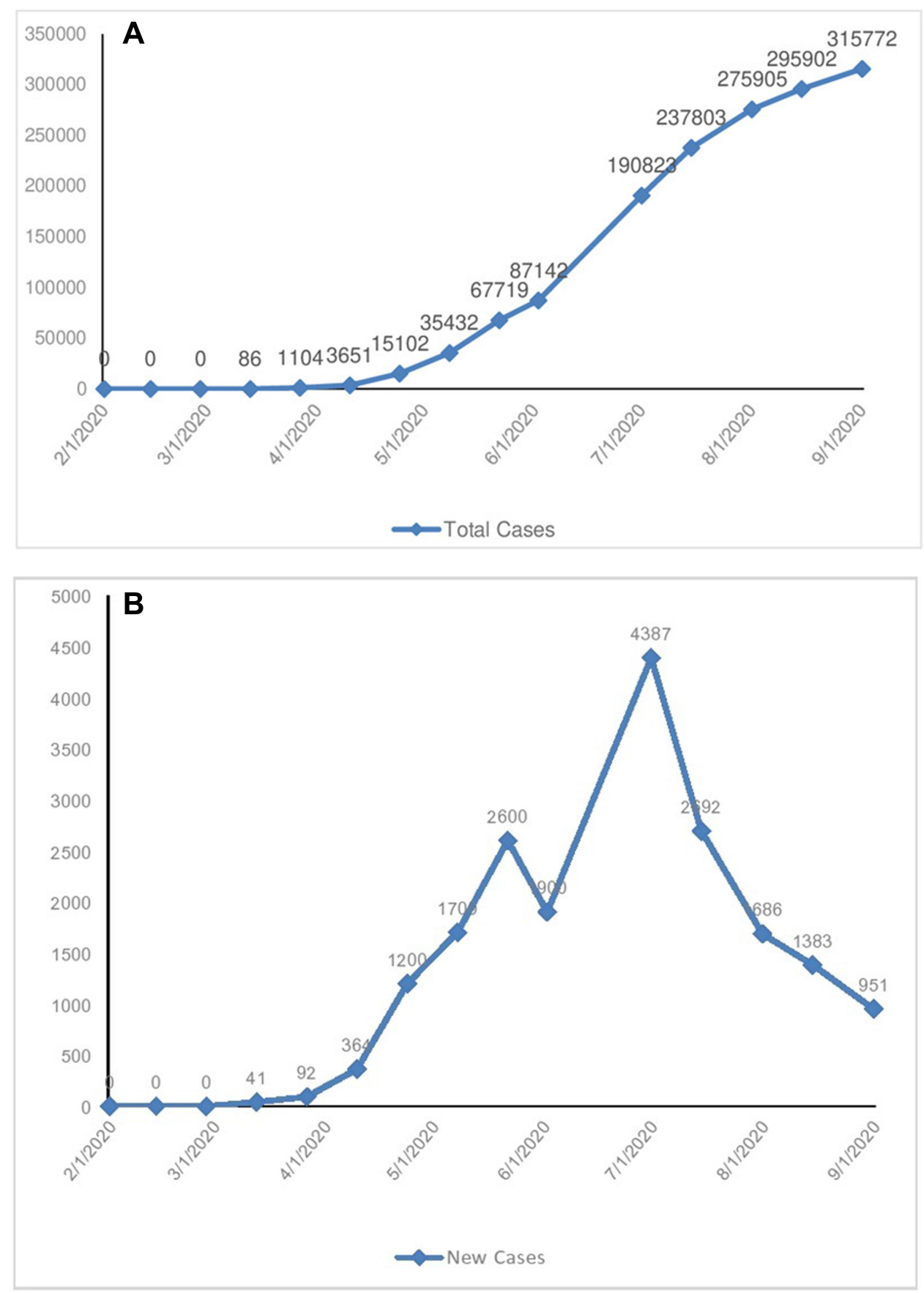

Figure 5 (A) Total COVID-19 cases in Saudi Arabia. (B) Daily new cases of COVID-19 in Saudi Arabia.

2 months. Thus, it can be observed that China, using its wide base of resources and technological interventions, has turned the crisis into an opportunity, by rapidly implementing containment strategies with strict implementation of lockdown (suppression strategy).

As for Italy, this country was in a similar situation to that of the United Kingdom, which acted belatedly to contain the infected areas. However, the country mounted its test strategy, and very quickly a large number of cases were identified and the lockdown was implemented at the national level as a method of prevention and repression. ${ }^{41}$ It can be seen that despite the lockdown, the total confirmed COVID-19 cases in Italy (Figure 4A) have increased rapidly since the lockdown was implemented, indicating that the strategy could have been poorly executed or implemented too late, or that other conditions 

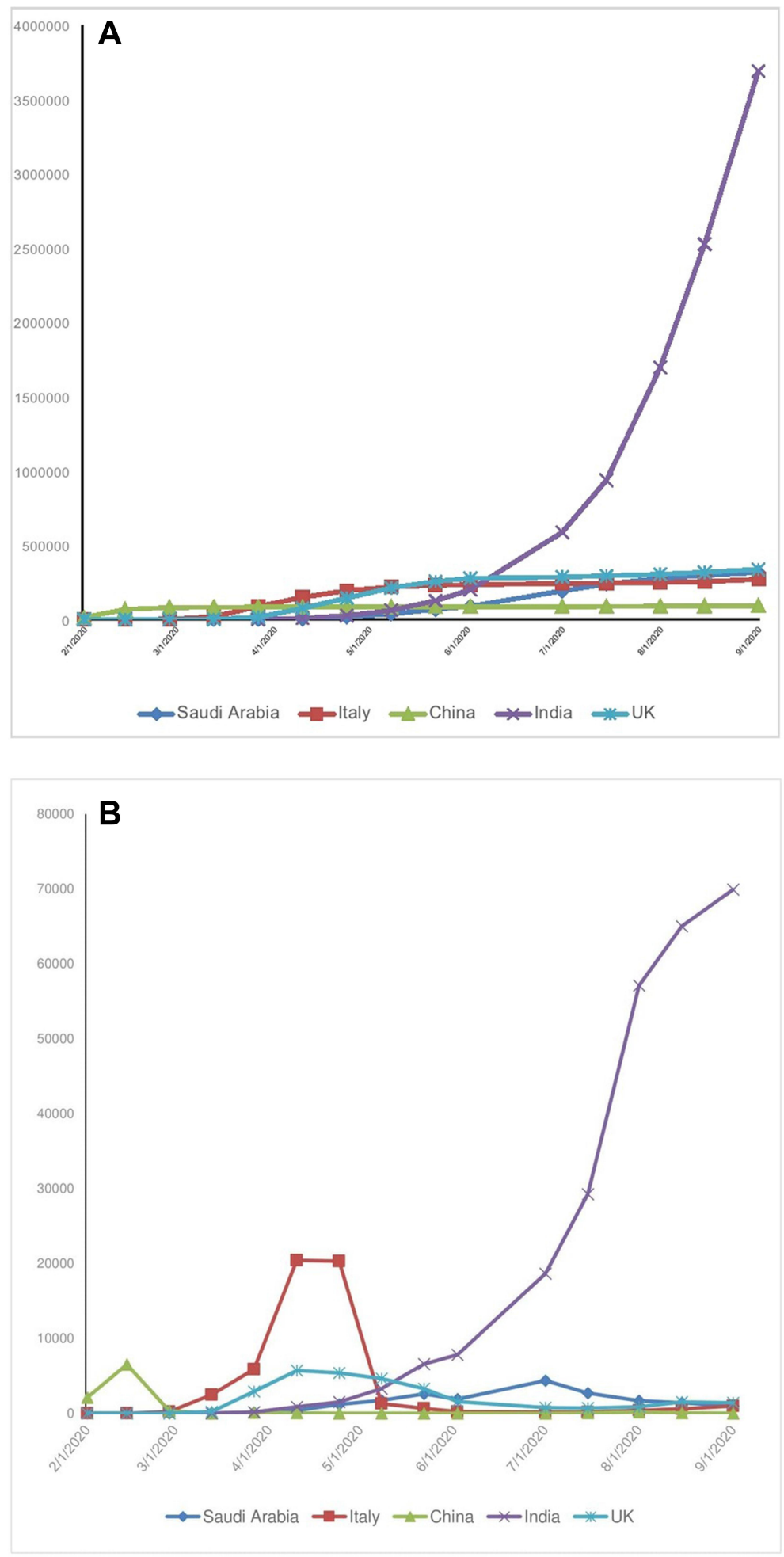

Figure 6 (A) Comparison of total COVID-19 cases in China, India, Saudi Arabia, Italy, and the United Kingdom. (B) Comparison of daily new cases of COVID-19 in China, India, Saudi Arabia, Italy, and the United Kingdom.

such as lack of awareness of the population or absence of sufficient health resources prevailed. ${ }^{41}$ Comparing the number of new cases per day (Figure 4B), there has been a steady decrease since the first week of May after the lockdown was implemented, which can be attributed to the application of suppression strategies. However, since June there is a steady increase in the number of cases which is a great concern. Although the country began to ease 
Table I Strategies Assumed by the Health Authorities of Each Country

\begin{tabular}{|c|c|c|}
\hline Country & $\begin{array}{l}\text { Date of Starting the Cases } \\
\text { of CoVID-19 }\end{array}$ & $\begin{array}{l}\text { Strategy Assumed by the Health Authorities of Each Country to Contain the Spread } \\
\text { of the COVID-19 Virus }\end{array}$ \\
\hline China & December 8, 2019 & $\begin{array}{l}\text { On } 23 \text { January 2020, the government of China imposed a lockdown in Wuhan and other cities in } \\
\text { Hubei to quarantine the center of the } 2019 \text { corona virus (COVID-19) outbreak. }{ }^{33} \text { Since then, } \\
\text { China have adopted several strategies to contain the spread of the COVID-19 virus such as early } \\
\text { case detection, contact tracing, population behavioral change, creation of hospitals, and use of } \\
\text { existing primary care centers. }{ }^{33-35} \text { In addition, China has used advanced technologies such as } \\
\text { Artificial Intelligence and Machine Learning to develop applications for contact tracing, medical } \\
\text { diagnosis, and other COVID-19 operations. Drones were used for tracking, contact tracing, and } \\
\text { also for services delivery. }{ }^{36} \text { Similarly, robots were used in various services such as hospitals, } \\
\text { restaurants, and other areas, limiting human interactions during the epidemic. }{ }^{37} \text { Innovations in } \\
\text { biotechnology, hi-tech face masks and free online clinics were made. Also, virtual classrooms, } \\
\text { remote working, and unmanned automated retail stores were implemented to reduce } \\
\text { contamination. }{ }^{38} \text { Public risk communication and technical guidance activities have been carried } \\
\text { out to increase public awareness and adoption of self-protection measures. }{ }^{2} \text { On April } 8 \text {, after } 76 \\
\text { days, China lifted the lockdown in Wuhan. }\end{array}$ \\
\hline $\begin{array}{l}\text { United } \\
\text { Kingdom }\end{array}$ & January 3I, 2020 & $\begin{array}{l}\text { Initially, the UK implemented a strategy focused on building people immunity letting the virus to } \\
\text { spread to about half of the population. }{ }^{17} \text { However, as the number of positive cases increased, the } \\
\text { government changed its strategy of mitigation to a suppression approach (lockdown). }{ }^{17} \text { The } \\
\text { lockdown was implemented on March } 24,2020 \text {. The suppression applied measures include strict } \\
\text { lockdowns, social distancing, closure of educational institutions, businesses and community } \\
\text { places. }{ }^{17} \text { Since June I, } 2020 \text { the lockdown has been eased, and more emphasis has been placed on } \\
\text { testing, tracking, prevention, and use of contact tracing technologies. }{ }^{18,19}\end{array}$ \\
\hline India & January 30, 2020 & $\begin{array}{l}\text { India implemented a nation-wide lockdown on March 22, 2020, and adopted various suppression and } \\
\text { mitigation strategies through five phased lockdowns since March } 22 .{ }^{21,22} \text { Also, the country assumed a } \\
\text { testing strategy focused on risk and priority, where people with COVID-19 symptoms and a recent } \\
\text { history of international travel were identified for testing, rather than adopting a mass testing } \\
\text { strategy. }{ }^{21,22,24} \text { In addition, India launched campaigns for healthy foods, mandatory medicines such as } \\
\text { arsenic albumin and hydroxychloroquine. }{ }^{25} \text { Similarly, India launched the mobile contact tracing } \\
\text { application called "Arogya Setu" to identify the contaminated zones. }{ }^{27,28} \text { Another implemented strategy } \\
\text { was the cluster containment plan to detect high risk zones, which were divided in } 4 \text { categories: } \\
\text { containment, red, orange and green zones. }{ }^{29,30} \text { The lockdown was relieved on June I, } 2020 .{ }^{31}\end{array}$ \\
\hline Italy & February 2I, 2020 & $\begin{array}{l}\text { Italy implemented a national lockdown on March II, } 2020 .^{40} \text { The application of the lockdown and } \\
\text { containment strategies such as rapid tests, and the emergency responses of the healthcare system } \\
\text { has helped to manage the pandemic. }{ }^{41,43} \text { ICUs of several hospitals were vacated, regular } \\
\text { hospitalized patients were transferred to non- containment zones for availability of beds in the } \\
\text { infected zones, and rapid changes in the delivery of care according to the increase of patients } \\
\text { were other measures implemented in the country. }{ }^{4-44} \text { The country began to ease the lockdown } \\
\text { restrictions from May } 4,2020.44\end{array}$ \\
\hline $\begin{array}{l}\text { Saudi } \\
\text { Arabia }\end{array}$ & March 2, 2020 & $\begin{array}{l}\text { In Saudi Arabia, the following containment strategies were slowly implemented throughout } \\
\text { February and March:Umrah suspension }(27 / 02 / 2020) \text {; cancelation and restriction of sporting } \\
\text { events }(07 / 03 / 2020) \text {; closure of educational institutions }(09 / 03 / 2020) \text {; suspension of sport } \\
\text { competitions and banning of social events }(14 / 03 / 2020) \text {;closure of shopping malls, restaurants, } \\
\text { coffee shops, public parks ( } 15 / 03 / 2020) \text {; suspension of daily and Friday prayer in mosques ( } 17 / 03 / \\
2020) \text {;suspension of public transport, flights, trains, buses and taxis ( } 18 / 03 / 2020) \text {; partial curfew } \\
(23 / 03 / 2020) .{ }^{49} \text { The country's initial strategy were focused on mitigation; however, the country } \\
\text { slowly moved towards suppression strategies by implementing curfews and lockdowns through } \\
\text { April-May. }{ }^{49-51} \text { Various services were provided to the public through mobile applications (For } \\
\text { example, MAWID application for booking appointments), and drone technology was used for } \\
\text { contact tracing and surveillance. }{ }^{55} \text { The country has begun to ease the lockdown restrictions since } \\
\text { the end of May; however, the curfew continued until june } 21,2020 .{ }^{52-54}\end{array}$ \\
\hline
\end{tabular}


lockdown restrictions from May 4, there is a need to prevent a surge in cases, since preventive measures such as social distancing and the use of masks may not be adopted in the long term. Furthermore, speeches on herd immunity have not gained much interest in Italy, which is worrying because it may lead to a second outbreak. ${ }^{63}$

Considering Saudi Arabia, this country implemented a mitigation strategy followed by a repression strategy in a phased manner through the implementation of the curfew, the closure of public and community places, schools, universities, and then religious places. ${ }^{49}$ In other words, instead of implementing a total lockdown, Saudi Arabia took a phased approach by applying restrictions, and then moved to a full lockdown. ${ }^{49}$ Strict penalties for confinement offenses may be one reason for the few confinement offenses compared to India, the United Kingdom, and other countries. ${ }^{64}$ Consequently, according to Figure 5A, the total cases in Saudi Arabia increased at a slow rate until the last week of April, 2020. It can be seen that despite the lockdown, the total confirmed COVID-19 cases in Saudi Arabia increased rapidly, suggesting that the strategy (in phases) could have been implemented poorly, or applied too late. Comparing the number of new daily cases (Figure 5B), there was a constant increase in cases until the third week of May, after implementing the lockdown. However, a decrease in the number of new daily cases was observed from the last week of May to June. Then, the number of cases increased again during the month of July. From July to August, the daily appearance of new cases has begun to decrease.

Comparing the application of containment strategies in the United Kingdom, India, Italy, China, and Saudi Arabia, Figure 6A and B, show that China has achieved a greater success in flattening the curve compared to the other countries. According to Figure 6B, in China few daily cases have occurred since March. In other words, China has been the only country that has managed to keep the COVID-19 pandemic under control using effective containment strategies, as it was previously explained.

On the other hand, reductions in the number of daily cases (Figure 6B) were observed in the UK (since May 2020), Italy (since May 2020), and Saudi Arabia (since July 2020). Also, Figure 6A indicates that during the last 3 months (June, July, August) India has shown the highest growth in the total number of confirmed cases compared to China, Italy, the United Kingdom and Saudi Arabia. Similarly, Figure $6 \mathrm{~B}$ shows that the highest number of new daily cases of COVID-19 cases has appeared in India during June, July, and August. As described above,

this can be attributed to the appearance of new cases in the main cities with high population densities such as Mumbai, Delhi, Chennai, and other places where between 40 and $50 \%$ of the total confirmed cases have been found. ${ }^{60}$

Other reasons for this growth may be the sudden implementation of the lockdown (followed by four more phased lockdowns that severely impacted people), and the increased lockdown violations (reflecting the poor community mobilization, awareness creation, and ability to cater to the population needs) that happened after the first phase of the lockdown. ${ }^{65}$ Also, unlike, China, where food was delivered online through grocery apps and online bookings, people in India had to go out to buy food and daily essentials; in these circumstances, social distancing might have not taken into account in some areas.

It should be noted that in the lack of evidence regarding various aspects related to the control of the COVID-19 pandemic, the countries have adopted different mitigation and suppression strategies. There is still ambiguity about policies related to preventive measures such as social distancing, quarantine, lockdowns, preventive medication, vaccination, work policies and post-lockdown school/university policies, social gathering policies, and many other factors related to the pandemic. Therefore, cooperation between countries, sharing data related to the pandemic, vaccination, and other aspects can help in the fight against the pandemic. However, it may not be an easy task to implement strict policies in other countries, such as those implemented in China, due to various socio-cultural, political, technological, economic, and legal factors. Therefore, depending on the intensity of the transmission and based on local data on the clusters, the policies to contain COVID-19 must be updated regularly.

This study has some limitations, and one of them is related to the fact that only a review of the literature was used to perform the comparative analysis of the strategies used by China, Italy, Saudi Arabia, India, and the United Kingdom to contain the spread of the COVID-19 pandemic. Other methods, such as qualitative interviews, surveys, and quantitative methods, could complement and improve the quality of the data collected. Furthermore, this study only compared five countries from different geographic/climatic regions, focusing primarily on mitigation and suppression lockdown strategies and some technological interventions to combat the COVID-19 pandemic, but other strategies related to laboratory testing, 
vaccination, health, socioeconomic, political and cultural factors were not investigated. Likewise, it should be mentioned that in the analysis carried out in this study there is the possibility of biases in the data provided by the respective countries. Another limitation of this study was that no statistical analysis of the data was performed. Future studies should be aimed at minimizing these limitations. In any case, this work contributes to updating the current literature in relation to the analysis of strategies to combat the COVID-19 pandemic.

\section{Conclusion}

The review of the strategies adopted by China, India, the United Kingdom, Italy, and Saudi Arabia to combat the COVID-19 pandemic can guide countries in the design and development of mitigation and suppression approaches to control the spread of the COVID-19 virus. Containment strategies such as lockdowns cannot continue in the long term. Therefore, countries must adopt mitigation and prevention strategies to protect people from infection and learn to live with the virus.

\section{Disclosure}

The authors report no conflicts of interest in this work.

\section{References}

1. Mayo Clinic. Coronavirus disease 2019 (COVID-19). Available from: https://www.mayoclinic.org/diseases-conditions/coronavirus/ symptoms-causes/syc-20479963. Accessed June 1, 2020.

2. Hui DS, Azhar E, Madani TA, et al. The continuing 2019-nCoV epidemic threat of novel coronaviruses to global health - the latest 2019 novel coronavirus outbreak in Wuhan, China. Int J Infect Dis. 2020;91:264-266. doi:10.1016/j.ijid.2020.01.009

3. World Health Organization. WHO coronavirus disease (COVID-19) dashboard. Available from: https://covid19.who.int/. Accessed June 1, 2020.

4. Nussbaumer-Streit B, Mayr V, Dobrescu A, et al. Quarantine alone or in combination with other public health measures to control COVID19: a rapid review. Cochrane Database Syst Rev. 2020;4.

5. Murthy S, Gomersall CD, Fowler RA. Care for critically ill patients with COVID-19. JAMA. 2020;323(15):1499. doi:10.1001/jama.20 20.3633

6. Velavan TP, Meyer CG. The COVID-19 epidemic. Trop Med Int Health. 2020;25(3):278-280. doi:10.1111/tmi.13383

7. CDC. Coronavirus Disease 2019 (COVID-19). Available from: https://www.cdc.gov/coronavirus/2019-ncov/prevent-getting-sick/ how-covid-spreads.html. Accessed June 1, 2020.

8. Bourouiba L. Turbulent gas clouds and respiratory pathogen emissions. JAMA. 2020. doi:10.1001/jama.2020.4756

9. Salehi S, Abedi A, Balakrishnan S. et al. Coronavirus disease 2019 (COVID-19): A systematic review of imaging findings in 919 patients. Am J Roentgenol. 2020:1-7. doi:10.2214/AJR.20.24425

10. Anderson R, Hans H, Don K, et al. How will country-based mitigation measures influence the course of the COVID-19 epidemic? Lancet. 2020;395(10228):931-934. doi:10.1016/S0140-6736(20)30567-5
11. Kassem AM. COVID-19: mitigation or suppression? Arab J Gastroenterol. 2020;21(1):1-2. doi:10.1016/j.ajg.2020.04.010

12. World Economic Forum. COVID-19: what the evidence so far means for containment. Available from: https://www.weforum.org/agenda/ 2020/04/covid-19-containment-suppression-strategy/. Accessed June 2, 2020

13. Liu Y, Albert A, Annelies W, et al. The reproductive number of COVID-19 is higher compared to SARS coronavirus. J Travel Med. 2020;27(2). doi:10.1093/jtm/taaa021.

14. Mizumoto K, Kagaya K, Zarebski A, et al. Estimating the asymptomatic proportion of coronavirus disease 2019 (COVID-19) cases on board the Diamond Princess cruise ship, Yokohama, Japan (PDF). Euro Surveill. 2020;25(10).

15. Wilson L. SARS-CoV-2, COVID-19, infection fatality rate (IFR) implied by the serology, antibody, testing in New York City. SSRN 3590771

16. World Health Organization. The United Kingdom. Available from: https://covid19.who.int/region/euro/country/gb. Accessed June 2, 2020.

17. Burgess M. When will lockdown end? The UK's lockdown rules, explained. Available from: https://www.wired.co.uk/article/uk-lock down. Accessed June 2, 2020.

18. Sparrow A, Murray J, Mohdin A. UK coronavirus: matt Hancock insists contact tracing system works; official death toll rises by 111 to $39,045-$ as it happened. Available from: https://www.theguardian.com/politics/ live/2020/jun/01/uk-coronavirus-live-england-schools-reopen-lock down-eases-covid-19-latest-updates. Accessed June 2, 2020.

19. Offshore. Subsea UK members adapting technologies for coronavirus containment. Available from: https://www.offshore-mag.com/busi ness-briefs/coronavirus/article/14173643/subsea-uk-members-adapt ing-technologies-for-coronavirus-containment. Accessed June 3, 2020.

20. World Health Organization. India. Available from: https://covid19. who.int/region/euro/country/in. Accessed June 2, 2020.

21. Gupta S. In India's Covid-19 testing strategy, a hard push from PM Modi and a dose of reality. Available from: https://www.hindustan times.com/india-news/in-india-s-covid-19-testing-strategy-a-hardpus h-from-pm-modi-and-a-dose-of-reality/storyOdltrmDPeTD4BRPUEM0qMP.html. Accessed June 2, 2020.

22. Times of India. Covid-19: A 'herd immunity' strategy could actually work in youthful India. Available from: https://timesofindia.india times.com/india/covid-19-a-herd-immunity-strategy-could-actuallywork-in-youthful-india/articleshow/75287811.cms. Accessed June 2, 2020.

23. The Lancet. COVID-19 dashboard by the center for systems science and engineering (CSSE) at Johns Hopkins University; 2020. Available from: https://www.arcgis.com/apps/opsdashboard/index. html\#/bda7594740fd40299423467b48e9ecf6. Accessed June 2, 2020.

24. Bindal A, Saha SK. Why lockdown is the best strategy for India to fight COVID-19? Available from: https://niti.gov.in/why-lockdownbest-strategy-india-fight-covid-19. Accessed June 2, 2020.

25. Adil M. Coronavirus in India: recovery rate improves to 48 per cent, fatality rate stands at 2.8 per cent. Available from: https://www.time snownews.com/india/article/coronavirus-in-india-recovery-rateimproves-to-48-per-cent-fatality-rate-stands-at-2-8-per-cent/599929. Accessed June 2, 2020.

26. Menon S, Thacker T. Can 'Ars Alb-30' protect you from Covid-19? AYUSH Ministry thinks so. Available from: https://economictimes. indiatimes.com/industry/healthcare/biotech/pharmaceuticals/can-arsalb-30-protect-you-from-covid-19-ayush-ministry-thinks-so/article show/74945805.cms?from=mdr. Accessed June 2, 2020.

27. CNBC. Coronavirus News highlights: Aarogya Setu is most-downloaded COVID-19 app. Available from: https://www.cnbctv18.com/ politics/coronavirus-news-live-updates-india-corona-vaccine-covid19-cure-maharashtra-mumbai-kolkata-delhi-gujarat-indore-flightsschedule-today-air-travel-process-train-tickets-lockdown-exit-26000581.htm. Accessed June 2, 2020. 
28. Singh M. India's contact-tracing app is going open-source. Available from: https://techcrunch.com/2020/05/26/aarogya-setu-india-sourcecode-release/. Accessed June 2, 2020.

29. Krishnakumar B, Rana S. COVID 19 In INDIA: strategies to combat from combination threat of life and livelihood. J Microbiol Immunol Infect. 2020;53(3):389-391. doi:10.1016/j.jmii.2020.03.024

30. World Economic Forum. Why India has the upper hand against COVID-19. Available from: https:/www.weforum.org/agenda/2020/ 04/india-covid19-coronavirus-response-kerala-uttar-pradesh/. Accessed June 2, 2020.

31. Dash S. India's red, green and orange zones have been designed wrong, say experts. Available from: https://www.businessinsider.in/ india/news/india-red-green-and-orange-zones-have-been-designedwrong-say-experts/articleshow/75620266.cms. Accessed June 2, 2020.

32. World Health Organization. China. Available from: https://covid19. who.int/region/wpro/country/cn. Accessed June 2, 2020.

33. Maier B, Brockmann D. Effective containment explains subexponential growth in recent confirmed COVID-19 cases In China. Science. 2020;368(6492):742-746. doi:10.1126/science.abb4557

34. The Lancet. Sustaining containment of COVID-19 in China. Lancet. 2020;395(10232):1230.

35. Liu X, Geoffrey J, Shouyang W, et al. Modeling the situation of COVID-19 and effects of different containment strategies in China with dynamic differential equations and parameters estimation, 2020.

36. Skorup B, Haaland C How drones can help fight the coronavirus. Mercatus Center Research Paper Series. Special Edition Policy Brief. SSRN; 2020. doi:10.2139/ssrn.3564671

37. Khan Z, Siddique A, Lee W. Robotics utilization for healthcare digitization in global COVID-19 management. Int $J$ Environ Res Public Health. 2020;17(11):3819. doi:10.3390/ijerph17113819

38. López-Varela S, González-Gross M, Marcos A. Functional foods and the immune system: a review. Eur J Clin Nutr. 2002;56(3):29-33.

39. Diamandis. Learning from China: 7 hi-tech strategies for pandemic containment. Available from: https://www.diamandis.com/blog/ covid-19-learning-from-china-high-tech-strategies. Accessed June 2, 2020.

40. World Health Organization. Italy. Available from: https://covid19. who.int/region/euro/country/it. Accessed June 2, 2020.

41. Gatto M, Bertuzzo E, Mari L, et al. Spread and dynamics of the COVID-19 epidemic in Italy: effects of emergency containment measures. Proc Natl Acad Sci. 2020;117(19):10484-10491. doi:10.1073/pnas.2004978117

42. Economic Times. Lessons countries can learn from COVID-19 in Italy decoded. Available from: https:/economictimes.indiatimes.com/ news/international/world-news/lessons-countries-can-learn-fromcovid-19-in-italy-decoded/articleshow/75105308.cms?from=mdr. Accessed June 2, 2020.

43. Grasselli G, Pesenti A, Cecconi M. Critical care utilization for the COVID-19 outbreak in Lombardy, Italy. JAMA. 2020;323(16):1545. doi:10.1001/jama.2020.4031

44. Lutz R. Detailing the steps Italy took to mitigate their coronavirus crisis. Available from: https://www.contagionlive.com/news/detail ing-the-steps-italy-took-to-mitigate-their-coronavirus-crisis. Accessed June 2, 2020.

45. World Health Organization. Saudi Arabia. Available from: https:// covid19.who.int/region/emro/country/sa. Accessed June 2, 2020.

46. Kingdom of Saudi Arabia. Vision 2030. Available from: https://www. ncbi.nlm.nih.gov/pmc/articles/PMC7172679/\#bib6. Accessed June 2, 2020.

47. Abdul Salam A, Elsegaey I, Khraif R, et al. Population distribution and household conditions in Saudi Arabia: reflections from the 2010 Census. Springer Plus. 2014;3:530. doi:10.1186/2193-1801-3-530

48. Lee VJ, Chiew CJ, Khong WX. Interrupting transmission of COVID19: lessons from containment efforts in Singapore. J Travel Med. 2020;27(3). doi:10.1093/jtm/taaa039
49. Yezli S, Khan A. COVID-19 Social distancing in the Kingdom of Saudi Arabia: bold measures In the face of political, economic, social and religious challenges. Travel Med Infect Dis. 2020;101692. doi:10.1016/j.tmaid.2020.101692

50. Ebrahim S, Ziad A. COVID-19 - the role of Mass Gatherings. Travel Med Infect Dis. 2020;34:101617. doi:10.1016/j.tmaid.2020.101617

51. Algaissi A, Alharbi NK, Hassanain M, et al. Preparedness and response to COVID-19 in Saudi Arabia: building on MERS experience. J Infect Public Health. 2020;13(6):834-838. doi:10.1016/j. jiph.2020.04.016

52. Obaid R. Life is sweet as Saudi children say goodbye to lockdown. Available from: https://www.arabnews.com/node/1682851/saudi-ara bia. Accessed June 2, 2020.

53. Singh P. Saudi Arabia to impose full lockdown during Eid holiday from May 23-27. Available from: https:/www.hindustantimes.com/ world-news/saudi-arabia-to-impose-full-lockdown-during-eid-holi day-from-may-23-27/story-H7XxIEMIHedLOYLumBgKoM.html. Accessed June 2, 2020.

54. Aljazeera. Saudi Arabia to end curfew on June 21, except in Mecca. Available from: https://www.aljazeera.com/news/2020/05/saudi-ara bia-curfew-june-21-mecca-200526021532944.html. Accessed June 2, 2020.

55. Benny J. Saudi Arabia's technology investments pay off in coronavirus battle. Available from: https://www.cio.com/article/3535801/ saudi-arabias-technology-investments-pay-off-in-coronavirus-battle. html. Accessed June 2, 2020.

56. Karthikeyan G. Tracking the impact of interventions against COVID19 in absence of extensive testing. Indian J Med Res. 2020. doi:10.4103/ijmr.IJMR_864_20

57. Horton R. Offline: COVID-19-A reckoning. Lancet. 2020;395 (10228):935. doi:10.1016/S0140-6736(20)30669-3

58. O'Grady C. The U.K. backed off on herd immunity. To beat COVID19, we'll ultimately need it. Available from: https://www.nationalgeo graphic.com/science/2020/03/uk-backed-off-on-herd-immunity-tobeat-coronavirus-we-need-it/. Accessed June 3, 2020.

59. BBC. Coronavirus: lockdown easing in England 'modest' - Jenrick. Available from: https://www.bbc.com/news/uk-52869875\#. Accessed June 2, 2020

60. Prasad R. Coronavirus | over 50\% of COVID-19 cases, deaths are from five Indian cities. Available from: https://www.thehindu.com/ sci-tech/health/coronavirus-over-50-of-covid-19-cases-deaths-arefrom-five-indian-cities/article31711640.ece. Accessed June 2, 2020.

61. Costello A. The UK's Covid-19 strategy dangerously leaves too many questions unanswered. The Guardian. 2020. Available from: https:// www.theguardian.com/commentisfree/2020/mar/15/uk-covid-19-strat egy-questions-unanswered-coronavirus-outbreak. Accessed June 3, 2020.

62. Rapoza K. How Singapore and South Korea deal with coronavirus quarantine measures. Forbes;. 2020. Available from: https://www. forbes.com/sites/kenrapoza/2020/03/26/how-singapore-and-southkorea-deal-with-coronavirus-quarantine-measures/\#6a8dcccc1921. Accessed June 3, 2020.

63. Laterza V. The rushed easing of lockdown measures could devastate Italy. Available from: https://www.aljazeera.com/indepth/opinion/ rushed-e as in g- 1 o ckdown-measures-devas t a te-i taly200526112110970.html. Accessed June 2, 2020.

64. Hindustan Times. Hefty fine, jail for violators of Covid-19 lockdown curbs in Saudi Arabia. Available from: https://www.hindustantimes. com/world-news/saudi-arabia-forms-police-unit-to-enforce-corona virus-curbs/story-LhIk7LHlrr59Ds7LL4bCcN.html. Accessed June 3 2020.

65. India Today. Coronavirus: social distancing violations increase as India eases lockdown restrictions. Available from: https:/www.india today.in/india/story/coronavirus-scare-social-diatancing-normsflouted-india-1684913-2020-06-03. Accessed June 3, 2020. 


\section{Publish your work in this journal}

The Journal of Healthcare Leadership is an international, peer-reviewed, open access journal focusing on leadership for the health profession The journal is committed to the rapid publication of research focusing on but not limited to: Healthcare policy and law;Theoretical and practical aspects healthcare delivery; Interactions between healthcare and society and evidence-based practices; Interdisciplinary decision-making;

Submit your manuscript here: https://www.dovepress.com/journal-of-healthcare-leadership-journal
Philosophical and ethical issues; Hazard management; Research and opinion for health leadership; Leadership assessment. The manuscript management system is completely online and includes a very quick and fair peer-review system. Visit http://www.dovepress.com/ testimonials.php to read real quotes from published authors. 